Terbit online pada laman web jurnal : http://e-journal.sastra-unes.com/index.php/JIPS

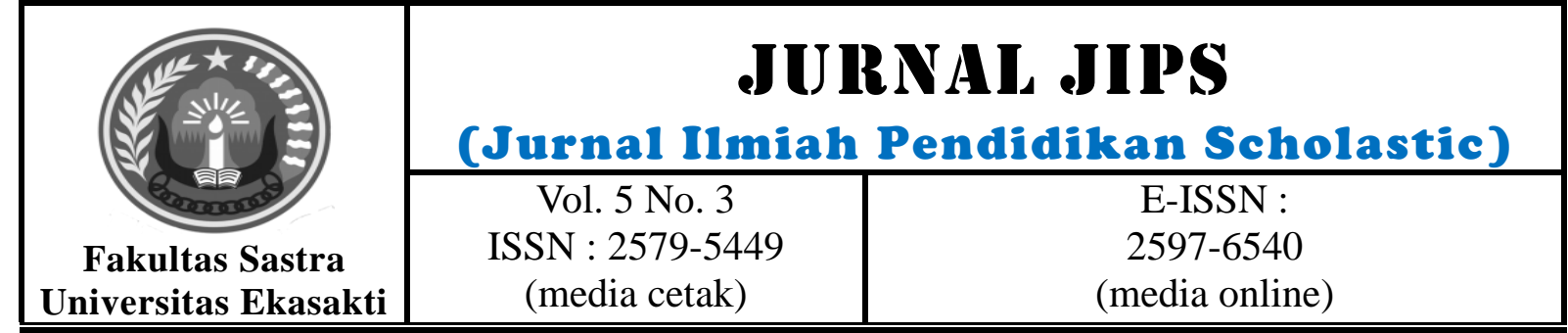

\title{
PENGEMBANGAN MODUL DENGAN PERPADUAN MIND MAPPING DALAM PEMBELAJARAN MATEMATIKA UNTUK MENGETAHUI AKTIVITAS DAN HASIL BELAJAR SISWA KELAS VII SMP PERTIWI I PADANG
}

\author{
Khurnia Budi Utami \\ Program Studi Pendidikan Matematika \\ Universitas Ekasakti Padang \\ Khurnia2018@gmail.com
}

\begin{abstract}
Abstrak
Seorang guru dituntut tidak hanya mampu menggunakan media pembelajaran yang telah disediakan oleh sekolah, tetapi juga harus mampu menciptakan suatu media pembelajaran yang akan digunakannya apabila media itu belum tersedia, serta tidak tertutup kemungkinan bahwa media tersebut juga harus tepat dan sesuai dengan perkembangan dan tuntutan zaman. Penggunaan media pembelajaran yang tepat akan sangat membantu keefektifan proses pembelajaran di sekolah. Selain membangkitkan motivasi belajar siswa, media pembelajaran juga dapat membantu siswa meningkatkan pemahaman terhadap materi yang akan diajarkan.

Jenis penelitian ini adalah penelitian pengembangan atau Development Research. Model pengembangan perangkat pembelajaran yang dapat digunakan adalah 4-D models. Model ini terdiri atas empat tahap, yakni define, design, develop, dan disseminate. Pada penelitian ini, penulis hanya menggunakan 3 tahapan dari 4-D models, yaitu tahap define, design, dan develop. Modul matematika yang telah didesain, kemudian divalidasi oleh empat orang validator terdiri dari dua orang dosen matematika, satu orang dosen bahasa indonesia, dan satu orang guru matematika. Modul matematika yang telah divalidasi kemudian direvisi berdasarkan saran validator ahli. Modul matematika yang telah divalidasi dan direvisi tersebut dianggap telah memenuhi kriteria kevalidan dan dapat digunakan.

Hasil validasi modul matematika dengan perpaduan Mind Mapping menurut ahli materi materi dan pembelajaran matematika sudah termasuk kategori valid dengan persentase $86,25 \%$ dan dapat digunakan dengan sedikit revisi. Hasil validasi modul matematika dengan perpaduan Mind Mapping menurut ahli tata bahasa sudah termasuk kategori valid dengan persentase 83,3\% dan dapat di gunakan dengan sedikit revisi. Praktikalitas pembelajaran matematika dengan menggunakan modul matematika dengan perpaduan Mind Mapping termasuk dalam kategori sangat praktis dengan persentase $86,25 \%$.
\end{abstract}

Keywords: Modul, Mind Mapping

(C) 2021 Jurnal JIPS

Jurnal JIPS (Jurnal Ilmiah Pendidikan Scholastic ) Vol. 5 No. 3 (2021) ISSN : 2579-5449

This work is licensed under a Creative Commons Attribution-NonCommercial 4.0 International License. 


\section{INTRODUCTION}

Pada umumnya, siswa masih saja cenderung memandang matematika itu sebagai mata pelajaran yang tidak menyenangkan, sulit dan membosankan. Hal ini mungkin disebabkan karena matematika banyak memuat konsepkonsep yang bersifat abstrak, rumus-rumus yang rumit dan sulit untuk dipahami oleh sebagian siswa, sehingga pelajaran matematika terkesan menjadi sangat membosankan bagi siswa.

Anggapan tentang matematika itu sulit semakin kompleks dengan buku matematika yang setiap halamannya berbaris rapi rumusrumus yang membuat mata siswa malas melihatnya dan tak jarang siswa hanya menyalin dan mencatat apa yang di jelaskan oleh guru didepan kelas, Selain itu guru dalam proses pembelajaran masih belum menggunakan bahan ajar pembelajaran yang bervariasi dan menarik. Dari hal itu terlihat bahwa siswa memerlukan suatu bahan ajar yang menarik yang dapat digunakan dalam proses pembelajaran agar

\section{RESEARCH METHODS}

Peneliti ini menggunakan model
pengembangan 4-D (Define, $\begin{array}{r}\text { Design, } \\ \text { dengan }\end{array}$
Development, and Disseminate)
pendekatan deskriptif yang berorientasi pada
pengembangan produk. Tahap Pendefenisian
(Define) adalah menetapkan dan mendefenisikan
syarat-syarat pembelajaran diawali dengan
analisis tujuan dari batasan materi yang
dikembangkan perangkatnya. Tahap ini meliputi
analisis awal-akhir, analisis siswa, analisis
konsep, analisis tugas, perumusan / spesifikasi
tujuan pembelajaan. Tahap Perancangan
(Design) Tujuan dari tahap ini adalah
menyiapkan prototipe perangkat pembelajaran.
Tahap ini terdiri dari penyusunan tes, pemilihan
media, pemilihan format, rancangan awal. Tahap
Pengembangan (Develop) Tujuan pada tahap ini
adalah untuk menghasilkan modul dengan
perpaduan Mind Mapping berdasarkan masukan
dari para ahli.

Peneliti ini menggunakan model pengembangan 4-D (Define, Design pendekatan deskriptif yang berorientasi pada pengembangan produk. Tahap Pendefenisian (Define) adalah menetapkan dan mendefenisikan syarat-syarat pembelajaran diawali dengan analisis tujuan dari batasan materi yang dikembangkan perangkatnya. Tahap ini meliputi analisis awal-akhir, analisis siswa, analisis konsep, analisis tugas, perumusan / spesifikasi tujuan pembelajaan. Tahap Perancangan (Design) Tujuan dari tahap ini adalah Tahap ini terdiri dari penyusunan tes, pemilihan media, pemilihan format, rancangan awal. Tahap adalah untuk menghasilkan modul dengan dari para ahli. mereka dapat memahami materi dari penjelasan guru.

Dari penjelasan tersebut seharusnya dikeembangkan bahan ajar matematika yang sesuai dari permasalahan yang ditemui. Pemanfaatan bahan ajar ini membantu meningkatkan pemahaman siswa terhadap konsep matematika. Salah satu bahan ajar yang dapat dikembangkan dan dapat digunakan oleh siswa dalam proses pembelajaran adalah bahan ajar dalam bentuk modul dengan perpaduan Mind Mapping, yakni Modul dikembangkan sedemikian rupa dengan memadukan unsur Mind Mapping didalamnya sehingga siswa dapat memahami konsep, tanpa harus dijelaskan oleh guru secara keseluruhan. modul ini juga dikembangkan berdasarkan rencana pelaksanaan pembelajaran (RPP) dengan tujuan materi yang disajikan dalam Modul sesuai dengan waktu atau jadwal yang ditetapkan.
Uji coba Modul dengan perpaduan Mind
Mapping dilakukan dengan tujuan untuk mendapatkan informasi apakah produk yang dikembangkan lebih praktis. Jenis data dalam penelitian ini adalah data primer. Data primer adalah data yang diperoleh secara langsung. Lembar validasi terdiri dari: Lembar validasi modul, Lembar validasi angket praktikalitas, Lembar validasi soal tes hasil belajar, Lembar validasi observasi aktivitas siswa. Angket praktikalitas digunakan untuk menilai kepraktisan bahan ajar berupa modul dengan perpaduan Mind Mapping ini. Lembar Observasi Aktivitas Siswa adalah mengamati aktivitas siswa pada saat proses pembelajaran. Hasil belajar siswa dapat diketahui dengan melakukan penilaian kepada responden penelitian melalui tes. 


\section{RESULTS AND DISCUSSION}

Hasil validasi modul matematika dengan perpaduan Mind Mapping menurut ahli materi materi dan pembelajaran matematika sudah termasuk kategori valid dengan persentase $86,25 \%$ dan dapat digunakan dengan sedikit revisi. Hasil validasi modul matematika dengan perpaduan Mind Mapping menurut ahli tata bahasa sudah termasuk kategori valid dengan persentase $83,3 \%$ dan dapat di gunakan dengan sedikit revisi.

Data praktikalitas diperoleh melalui angket praktikalitas. hasil presentase kepraktisan modul dengan perpaduan Mind Mapping dalam pembelajaran matematika siswa adalah $86,25 \%$ dan termasuk dalam kategori sangat praktis.

Selama proses pembelajaran dilakukan observasi aktivitas siswa yang diisi oleh seorang observer, penilaian ini dilakukan untuk melihat respon siswa terhadap pembelajaran menggunakan modul dengan perpaduan Mind Mapping. Selama pembelajaran seluruh aktivitas siswa dalam kelas akan dinilai berdasarkan indikator yang ada pada lembar observasi aktivitas siswa.

Analisis data dari pertemuan pertama, kedua, ketiga dan keempat perkembangan aktivitas belajar siswa berbeda-beda. Pada indikator penilaian pertama perkembangan aktivitas siswa pada pertemuan pertama dan kedua sama yaitu 22 siswa,kemudian pada pertemuan ketiga dan jumlah siswa yang aktif bertambah menjadi 27 siswa dan pertemuan keempat jumlah siswa yang aktif semakin bertambah yaitu 30 siswa. Indikator penilaian yang kedua, siswa yang aktif pada pertemuan pertama sebanyak 21 siswa, pada pertemuan yang kedua dan ketiga jumlah siswa yang aktif semakin meningkat yaitu 23 siswa dan 25 siswa, namun pada pertemuan keempat jumlah siswa yang aktif sedikit menurun namun tidak lebih rendah dari pertemuan kedua yaitu 24 siswa.

Indikator penilaian yang ketiga jumlah siswa yang aktif pada pertemuan pertama sebanyak 28 siswa, selanjunnya pada pertemuan keduan dan ketiga jumlah siswa yang aktif menurun yaitu 26 siswa menurun lagi sebanyak 21 siswa, pada pertemuan keempat siswa yang aktif kemabali bertambah yaitu sebanyak 25 siswa. Indikator penilaian yang keempat, siswa yang mengajukan pertanyaan sesuai materi yang telah disampaikan pada pertemuan pertama sebanyak 12 siswa, bertambah lagi menjadi 22 siswa pada pertemuan kedua, dan pada pertemuan ketiga menurun lagi yaitu sebanyak 19 siswa dan pada pertemuan keempat jumlah siswa yang aktif sama dengan pada pertemuan ketiga.

Indikator penilaian yang kelima siswa yang mengerjakan tugas yang diberikan guru dari petemuan pertama, keduan dan ketiga semakin menurun yaitu di 30 siswa menurun menjadi 27 siswa, kemudian menurun lagi menjadi 26 siswa, namun pada pertemuan keempat kembali bertambah yaitu sebanyak 28 siswa. Pada indikator penilaian keenam jumlah siswa yang bersedia mengerjakan latihan di papan tulis pada pertemuan pertama sebanyak 27 siswa, pertemuan keduan menurun menjadi 25 , kembali bertambah pada pertemuan ketiga yaitu sebanyak 27 siswa dan menurun lagi pada pertemuan keempat sebanyak 23 siswa dengan jumlah persentase per indikator yaitu $85 \%$.

Pada indikator penilaian yang ketujuh siswa menanggapi, menganalisis, melihat hubungan, dan menyimpulkan pembelajaran pada pertemuan pertama, kedua, dan ketiga semakin menurun yaitu dari 21 siswa menurun menjadi 18 siswa dan menurun lagi menjadi 15 siswa, selanjutanya pada pertemuan keempat adanya peningkatan jumlah siswa yang aktif yaitu sebanyak 23 siswa jauh lebih tinggi dibandingkan jumlah pada pertemuan pertama, dengan jumlah persentase per indikator yaitu $64,1 \%$. Pada indikator penillaian yang kedelapan, siswa yang tenang dan tertib dalam mengikuti pembelajaran pada pertemuan pertama, kedua dan ketiga semakin meningkat tiap pertemuan yaitu 20 siswa pada pertemuan pertama, 23 siswa pada pertemuan kedua, 25 siswa pada pertemmuan ketiga dan pada pertemuan keempat mangalami penurunan yaitu 24 siswa dengan jumlah persentase per indikator yaitu 76,6\%.

$$
\text { Pada indikator penilaian yang }
$$

kesembilan siswa yang tidak keluar masuk saat guru menjelaskan teori pelajaran pada pertemuan pertama sebanyak 30 siswa selanjutnya pada pertemuan kedua siswa yang aktif menurun yaitu 27 siswa, kemudian meningkat lagi pada 
pertemuan tiga yaitu 28 siswa dan pada pertemuan ke empat julah siswa yang aktif masih sama dengan pada pertemuan yang ketiga dengan jumlah persentase per indikator yaitu 94,1\% . Pada indikator penilaian yang terakhir, jumlah siswa yang membaca bahan ajar (Modul) pada pertemuan pertama, kedua, ketiga dan keempat naik turun yaitu dari 28 siswa kemudian menurun menjadi 25 siswa, naik lagi menjadi 30 siswa dan kembali turun menjadi 27 siswa dengan jumlah persentase per indikator yaitu $91,6 \%$. Jadi pada persentase aktivitas siswa seluruhnya dalam proses pembelajaran memiliki rata-rata persentase $80,83 \%$ sehingga sudah dapat dikategorikan aktif.

\section{CONCLUSION}

Hasil validasi modul matematika dengan perpaduan Mind Mapping menurut ahli materi materi dan pembelajaran matematika sudah termasuk kategori valid dengan persentase $86,25 \%$ dan dapat digunakan dengan sedikit revisi. Hasil validasi modul matematika dengan perpaduan Mind Mapping menurut ahli tata
Tes hasil belajar dilakukan pada kelas uji coba dengan jumlah siswa sebanyak 30 orang, soal dibagikan per siswa dengan jumlah soal sebanyak 10 soal. Persentase ketuntasan hasil belajar siswa pada tes secara keseluruhan adalah $83,3 \%$ dan sudah mencapai KKM yang ditetapkan. Dapat dijelaskan pada masing-masing data hasil belajar siswa yaitu: nilai tes yang terendah adalah 59 dan nilai tes tertinggi adalah 100. Siswa yang memperoleh nilai di atas KKM yaitu 80 ada sebanyak 25 orang, sedangkan siswa yang memperoleh nilai di bawah KKM ada sebanyak 5 orang. bahasa sudah termasuk kategori valid dengan persentase $83,3 \%$. Praktikalitas pembelajaran matematika dengan menggunakan modul matematika dengan perpaduan Mind Mapping termasuk dalam kategori sangat praktis dengan persentase $86,25 \%$. 


\section{Bibliography}

[1]A.M. Sardiman. 2011. Interaksi dan Motivasi Belajar Mengajar. Jakarta: Rajawali.

[2]Agus, Suprijono. 2011. Cooperative Learning Teori dan Aplikasi. PAIKEM. Yogyakarta: Pustaka Pelajar.

[3]Deni, Setiawan. DDK. 2003. Pengembangan Bahan ajar. Universitas Terbuka.

[4]Depdiknas. 2008. Panduan Pengembangan Bahan Ajar. Jakarta: Direktorat Jenderal Manajemen Pendidikan Dasar dan Menengah.

[5]Dimyati dan Mudjiono, 1999. Belajar dan Pembelajaran. Jakarta: Rineka Cipta.

[6]Dimyati, Mujiono. 2006. Belajar dan Pembelajaran. Cetakan ke-6. Jakarta: Rineka Cipta.

[7]Hanafiah, Nanang \& Cucu Suhana. 2010. Konsep Strategi Pembelajaran. Bandung: Refika Aditama.

[8]Kemendikbud. 2013. Materi Pelatihan Guru Implementasi Kurikulum 2013. Jakarta: Badan Pengembangan Sumber Daya Manusia Pendidikan dan Kebudayaan dan Penjaminan Mutu Pendidikan Kementrian Pendidikan dan Kebudayaan 2013.

[9]Majid, Abdul. 2006. Perencanaan Pembelajaran Mengembangkan Standar Kompetensi Guru. Bandung: PT Remaja Rosdakarya.

[10]Nasution , S. 2008. Berbagai pendekatan dalam proses Belajar Mengajar. Jakarta : Erlangga.

[11]Prastowo, Andi. 2011. panduan kreatif membuat bahan ajar inovatif. Yogyakarta: DIVA PRESS.

[12]Purwanto, Ngalim. 2009. Prinsip-prinsip dan teknik Evaluasi pengajaran. Bandung : PT. Remaja Rosdakarya.
[13]Rostikawati, T. 2008.Mind Mapping dalam metode quantum learning.

[14]Riduwan. 2006. Belajar muda penelitian. Bandung : Alfabeta.

[15]Rosma, Hartini Sam's. 2010. Model Penelitian Tindakan Kelas. Yogyakarta : Teras.

[16]Sardiman, 2001. Interaksi dan Motivasi Belajar Mengajar. Jakarta: PT. Raja Grafindo Persada.

[17]Slameto, 2003. Belajar dan Faktor-Faktor yang mempengaruhinya. Jakarta: Rineka Cipta.

[18]Soenarto. 2006. Metodologi penelitian pengembangan untuk Peningkatan Kualitas Pembelajaran. Jakarta: Depdiknas.

[19]Sudjana. Nana. 2009. Dasar-Dasar Proses Belajar Mengajar. Bandung: Sinar Baru Algesindo.

[20]Suherman, Erman , dkk. 2003. Strategi Pembelajaran Matematika Kontemporer.(edisi revisi). Bandung : FMIPA UPI.

[21]Sumiati dan Asra, m. 2009. Metode Pembelajaran. Bandung: CV Wacana Prima.

[22]Sujadi, 2002. Metodologi Penelitian Pendidikan. Jakarta: Rineka Cipta.

[23]Trianto. 2007. Model Pembelajaran Terpadu. Jakarta: Bumi Aksara.

[24]Van den Akker J. 1999. Principles and Methods of Development Rresearch. Pada J. Van den Akker, R.Branch, K. Gustafson, Niaven, dan T. Plomp (eds), Design Approaches and tools in Education and Training (pp. 1-14) Dortrech: Kluwer Academic Publishers 